\title{
TITHE HISTORY VALUE REACTUALISATION PROMOTING THE EFFICIENTLY IMPLEMENTATION OF ZAKAT MANAGEMENT
}

\author{
Cucu Solihah \\ Faculty of Law, Suryakancana University \\ Email: cucusolihah2012@gmail.com
}

\begin{abstract}
Two dimensions of zakat both religion and social give positive impact to society life, particularly in developing social responsibility. The Islamic history literature has recorded with golden ink the management of tithe which managed by the government, resulted the human prosperity which it proved the greatness of Islamic rule and the honor of human. The government has the strategic rule to realize the goal of tithe; Indonesia has the great potential to do it, since the majority of Indonesian peoples is moslem and there is a regulation that regulate it seriously to make the tithe as the potential alternative way to prevent poverty and to prosper society.
\end{abstract}

Key words: zakat, Islamic law, poverty, prosperity, welfare

\begin{abstract}
Abstrak
Dua dimensi zakat bagi agama dan sosial memberikan efek positif bagi kehidupan masyarakat, terutama dalam mengembangkan rasa tanggung jawab sosial. Literatur sejarah Islam telah mencatat dengan tinta emas dalam hal kesejahteraan masyarakat sebagai akibat dari sistem pengelolaan zakat yang dikelola oleh negara sehingga memberikan nuansa keagungan ajaran Islam dan kemuliaan manusia. Peran negara menjadi sangat strategis untuk merealisasikan tujuan zakat, terutama di Indonesia potensi zakat akan sangat potensial mengingat mayoritas penduduk muslim dan regulasi hukum telah memberikan celah sekaligus perhatian serius untuk menjadikan zakat sebagai sarana potensial penanggulangan kemiskinan dan mensejahterakan masyarakat.
\end{abstract}

Kata kunci: zakat, hukum Islam, kemiskinan, kesejahteraan.

\section{Introduction}

Tithe (zakat) has a value that fairly enough and also part of worship dimension, social, and economy with the objective as prevention of poverty so the society's prosperity is created. The objective had been achieved during Islam's prosperity period, by the difficulties of finding the one who entitled to receive tithe (Mustahik) and almost whole society of Madinah is prosperous by tithe. Through the good system of tithe management (professional and accountable) has made tithe as an instrument to enhance prosperity and reduce poverty, tithe will be a potential funding source that can be utilized to foster the general welfare of the entire community. ${ }^{1}$

\footnotetext{
1 Etty Rochaeti, “Analisis Mengenai Zakat Profesi Kaitannya dengan Pajak Penghasilan”, Legal Insight Journal, Vol. 24
}

Management of tithe that has been succeed and effectively implemented is able to lift up the poor to be affluent and does not depending on others, this is done through the implementation of well-managed tithe management system during the heyday of Islam. There is a perfect illustration in the system of tithe management of heyday Islamic period by participation of state in term of managing tithe as part of duties and obligations of the State so that the rights of citizens for welfare can be guaranteed.

The welfare which became goal of tithe management is as well as conforming to the objective of national development which are physical material - mental spiritual through improving adherence to God rule in the form of tithe

No. 1. February 2011, Bandung: Law Faculty of STHB, page 320. 
which give religion, social, and economic dimension by utilize the tithe fund. One of the way to realizing prosperous state is by the government intervention towards society in form of making rules and regulations so society's welfare can be achieved. ${ }^{2}$ The existed regulations that related with Law No. 23 Year 2011 about Tithe Management has opened a space for government as well as society to be directly involved on tithe management, in spite of the tithe management organization that already existed did not give significant influence for society's welfare development programs through efforts against poverty in Indonesia.

Based on the problem proposed above, there are several points need to be answered as follows. First, how is the history value of tithe management in Islam's heyday period that can be made as evaluation for tithe management in Indonesia?; and second, how is the tithe management system runs thus can be efficiently implemented to enhance the welfare in efforts against poverty and to change the mustahik (people who receive tithe) to be muzaki (people who give tithe)?

\section{Discussion}

\section{Historical Value of Tithe Management}

Tithe plays a very critical role in honoring Islam. Since the beginning of Islam development in Mecca, tithe continuously develop especially after the greatest prophet Muhammad passed away, by the onset of various ijtihad result of sahabah as form of law reformation. As an initiation of Islam state, Madina city has not had enough economy power particularly in state finance and fiscal policy. Rasulullah Mohammed as the highest authority holder in Madina accomplished an action to obtain state fund income. ${ }^{3}$

As the word of God that order Prophet Mohammad in his capacity as religion leader and also as government leader to collect tithe, thus the command indicates that government had

\footnotetext{
2 Cucu Solihah, "Negara Sejahtera dengan Memberdayakan Zakat melalui Fungsionalisasi Sistem Islam dan Hukum Administrasi Negara," Justitia Rostrum Law Journal, Vol. VI No. 01 January-June 2014, Cianjur: Law Faculty Suryakancana University, page 250.
}

given authorize to collect tithe from society. Tithe can served as source of state income and source of state expenditure, with the management system up to Baitulmal by embrace principle of balance budget, it means all of receipts used to state expenditures (government expenditures). State can facilitate the moslem society to do tithe obligation, although towards society that already have awareness in collecting tithe (self assessment) as influence of iman and taqwa they could count tithe and submit it to baitulmal.

After Rasul Mohammad SAW passed away, the next kholifah duty is to carrying out tithe law enforcement especially for society that reluctant to collect tithe (Riddah) with reason that the tithe is oblige collected to Prophet Mohammad only, and against groups that are reluctant to issue zakat to the head of the Islamic state, unless to issued tithe in their own environment. Kholifah Abu Bakr's period was able to restore the stability of the Islamic state and simultaneously be a clue that the sovereign has authority to make and implement legislation about zakat, there are also pattern of ijtihad in terms of utilization and distribution of zakat with not only on an understanding about 8 asnaf (recipients of Zakat as specified in Islam) also explored the property, objects/goods affected zakat, which in turn could boost the country's financial revenue from charity which, in turn, zakat contribute to welfare society.

Zakat in Umar al-Khattab era, developing ijtihad especially about honey zakat is not something that must be acquired from beekeepers; but becomes compulsory if the beekeepers themselves give zakat. Umar also showed that Zakat can be exchanged to form the price, i.e. in the value of money and the most controversial Umar ljtihad is, review the status of your reverts as one of asnaf (the Zakat receiver).

The Caliphs implement a concept of spending all deposits in Baitul Mal by not leaving

\footnotetext{
3 Mustafa Edwin Nasution, 2007, Pengenalan Ekslusif Ekonomi Islam, Jakarta: Kencana Prenada Media Group, page 205.
} 
remnants in each year because of accumulated possessions in Islamic Baitul Mal have to distribute to Muslims to meet the needs of Muslims, in addition there is also a serious concern and willingness of the Government (Political will) toward the officer by equality of position between the one who manage zakat with tax officers. Country treatment towards the two institution (tax and zakat) are the same, it is evidenced in the inauguration of officers of tithe with a guarantee of salary. Considering the tasks of both institution of include monitoring aspects, estimating zakat value and then taking zakat from the muzaki (the obligatory zakat) and monitor the collection of zakat.

Production efficiency of zakat that implemented by kholifahs also by using zakat fund for state necessities, for example Ali bin abu Thalib, he made policy of zakat management system that are: distribution all of income in baitulmal; navy's expenditures are eliminated; and policy of austerity. ${ }^{4}$ Mechanisms of governance management are reflected from the bureaucratic system which is abolished and Muslims can made complaints directly to the Caliph about misappropriation potency and zakat manager action that will harm the State, considering the acquisition of wealth zakat in Islamic Treasury (Baitul Mal) is enough potential.

The Kingdom established many public institutions such as Baitul Hikmah, a gathering place for the clever and astute scholar of Islam and issued new ideas and views to society as well as making hospitals, schools and so on. Based on Islam history about zakat management pattern, it can be quoted zakat management system which contain values of high civilization, modern and deserves to be re-examined in the management of zakat nowadays. Modern management system of zakat that imposed Islamic value contained clear goals through the process of planning, or-

\footnotetext{
4 M. Umar Chapra, 2001, Masa Depan Ilmu Ekonomi, Bandung: Gema Insani Press, page 155

5 Mulkanasir, "Mewujudkan Manajemen Zakat yang Modern dan Profesional", Empathy Journal of Social Welfare, Vol. 1 No. 2 January 2013, Jakarta: Social Welfare Studies Program Syarif Hidayatuloh Islamic State University, page 5257.

6 Bariadi dalam Dyah Esthi Perwitasari, “Karakteristik Mustahik dalam Penggunaan Dana ZIS dan Pegnaruhnya terha-
}

ganizing, moving, implementing up to clean and structured monitoring, by applying the essential elements as follows: have principles in management of zakat; having visions, missions and clear objectives; have a careful planning; operational; having a transparent financial system; have recruitment of Human resources (HR) pattern that are trusted; establish the principles of HR zakat recruitment; perform selection; do the placement and or assignment; and have the current concept of spiritual management. ${ }^{5}$

\section{Implementing the Efficient Zakat Management}

Welfare as the national development goal should be main priority, by increasing the welfare of society and to make it really depends from the ability to be able to escape from the snare of crisis and build more independent economic fundamentals. ${ }^{6}$ And Zakat as Islamic concept is to build a strong and independent economy foundation and be one solution for improving welfare. Value of Islamic administration system is realized in management of zakat system in Indonesia, especially in terms of state responsibility to form zakat management central BAZNAS institutions, provincial and district/city with amyl entitlements and operational costs are taken from the state budget.

The entry of the amil as zakat recipient after the poor, pointing out that zakat is not an obligation which is left to the individual, but task of institution or task of the Union, so the Government must manage, oversee and raise the amil to manage zakat, both as a collector, a cardboard, a book, or as a distributor. ${ }^{7}$ The presence of zakat influence for welfare provides awareness on the initiative of the management with modern system of tithes. The initiative of the management of zakat in Indonesia by society in the form of Institution Amil Zakat (LAZ) and in its development then the Government of Indo-

dap Probabitas Pengingkata Pendapatan Usaha (Studi Kasus Mustahik Peserta Program Pemberdayaan Ekonomi LAZ PKPU”, Exist Journal of Islamics Financial Economics and Business.Vol.4 No.2. April-June 2008, Jakarta: Specifity of Islamic Economy and Financial of Middle East and Islamics Study Program of Postgraduate Program Universitas Indonesia, page 106

7 Asnaini, 2008, Zakat Produktif dalam Perspektif Hukum Islam, Yogjakarta: Pustaka Pelajar, page 75. 
nesia participate in the management of zakat in Amil Zakat Nasional forms (BAZNAS) and make the regulatory management of zakat.

There is effort to centralize management institutions zakat by Badan Amil Zakat (BAZNAS) as an executive agency of government, but in the legal system of zakat management in Indonesia, centralized management of zakat is still acknowledge the existence of institutions zakat (LAZ) as management of zakat formed by people with functions as an auxiliary BAZNAS in managing a national zakat. Relating to the impact of zakat to reduce poverty, zakat utilized so as to lift the poor out of poverty and eliminate all factors that make poverty. The strategy was developed at the same time necessary in zakat-based empowerment program is to make the process of transformation mustahik be muzaki. ${ }^{8}$

The changing of status process from mustahik be muzaki through zakat inseparable from the proximity factor is a strong desire from the Government (Political will) to be convinced and believe that through zakat with professional management system will be the solution of poverty problem while zakat was made as part of the finances of the State. Zakat empowerment can be done by collecting zakat from obligatory zakat through the collection, management, distribution and utilization of zakat and conduct law enforcement efforts to the obligatory zakat. In terms of zakat empowerment implemented the provision of productive financing which is intended to meet the financing needs of production in the broadest sense, i.e. to improve the business, whether production, trade and investment.

Based on the type of financing productive requirements, it can be divided into two, namely: first, working capital financing, namely the financing needs for improved quantitative and qualitative production, as well as for trade needed or increased utility of place from an item; and second, investment financing, namely

\footnotetext{
8 Nana Mintarti, et.al. "Kajian Perumusan Performance Indikator bagi Program Pemberdayaan Masyarakat Berbasis Zakat." Journal of Thought and ldeas. Zakat \& Empowering. Vol.2. June 2009. Jakarta: IMZ The Indonesia Magnificence of Zakat, page 19.
}

financing to meet the needs of capital goods/capital goods as well as facilities which are closely related to the investment. Nowadays the national zakat potency is not explored completely especially in terms of form and all kinds of treasures that must be subject to zakat, including enforcement of the law for the compulsory zakat which do not carry out obligations as Muslims and obligations as citizens who obey the law provisions the management of zakat, so needed a legal determination strategy zakat (ijtihad) in determining the form, manner of tithes and study of mustahik (recipient of Zakah) adapted to the demands of public life and the development of targeted recipients of zakat as a form of diversity of thought.

The diversity of thought in the concept of zakat empowerment for mustahiks provide insight zakat provisions in a broader spectrum, as human effort to understand the verses of Quran, taking into account the objectives of Islamic law to preserve the religion, property, descent, aql and soul because ijtihad is a form of freedom to express a thought highly appreciated among jurists creators madzhab. ${ }^{9}$ Ijtihad in making zakat as the main facility of changing the status of "poor" to "afford" must be improved, significant changes in the welfare of society used to fulfill the needs of productive without leaving fulfilling consumer needs. The better use of zakat funds for entrepreneurial capital will further encourage the growth of operating income, success or failure of the programs depends on the utilization of zakat. With sharpness and precision of zakat will make a good program and would allocate funds collected on target. ${ }^{10}$

Zakat empowerment orientation toward food needs can be an indicator and as one of the instruments in describing the condition of poverty with known from the calculation of poverty based on public expenditure to food otherwise known as the food poverty line (FPL), this means that at the level of the minimum, the public will

\footnotetext{
9 Fokky Fuad, "Islam dalam Dinamika Filsafat Hukum, antara Pemaknaan Nilai Konstruktif dan Destruktif", Lex Jurnalica Journal. Vol. 10 No. 2 August 2013 Edition, Jakarta: Esa Unggul University, page 74.

10 Dyah Esthi Perwitasari, op.cit.
} 
be able to meet the basic needs of his family so as not to be in conditions of poverty. ${ }^{11}$ Required zakat management with professional management system with the obligation to record the data collection, distribution and utilization of zakat and property besides zakat. ${ }^{12}$ Supervision factors of the affluent class, estimating and take alms of muzaki fund (obligatory alms) and monitor billing Zakat becomes an inherent duty of zakat officers.

Zakat officers must have zakat utilization orientation to alleviate poverty and knew well the poverty indicators that one reason is as a result of the development is done in conventional and sectoral and centralized up, this is due to lack of participation potential of the grassroots so that the necessary development model with a model of civic governance approach the concept of participatory development in Indonesia. Model civic governance and participatory development concepts, trying to utilize all the potential that exists to develop/foster creative solutions in the management of development. ${ }^{13}$

During this time the effort of reducing poverty is solely understood as poverty eradication program and not as a policy of poverty reduction. As a result the efforts of poverty tend to be answered with the program for the poor that is funded by the state budget and private funds. Pro-poor budget for the poor policy results on fight-against poverty performance that is measured by how big the state budget funds allocated for poverty prevention program beside how far such efforts could lift poor people do not just come out of the pools of poverty, but also how to create a new middle class. ${ }^{14}$

\footnotetext{
${ }^{11}$ Purwanto, "Ketahanan Pangan, Kemiskinan dan Pembangunan Wilayah Perdesaan."Economics and Development. Vol. XX (1) June 2012, Bandung: University Publishing Centre (P2U-LPPM) Bandung Islamic University, page 65.

12 Circle Of Information And Development (CID), "Ringkasan Naskah Akademik Revisi UU Zakat”, Zakat \& Empowering Journal, Vol. 176 August 2008, Jakarta: Circle of Information and Development (CID) Dhuafa's Wallet Cooperate with Islamic Studies and Law Islamic of Law Faculty Universitas Indonesia, page 72.

${ }^{13}$ Rahman Mulyana, "Civil Governance melalui Partisipasi Masyarakat dalam Proses Penyelenggaraan Pemerintah", Journal of Social and Development Rostrum. Vol.28 No.2 December 2012 Edition, Bandung: University Publishing Centre (P2U-LPPM) Bandung Islamic University, page 158.
}

The existence of a clear surveillance system in the zakat management is to ensure the implementation of Islamic rule in society life. In practice, the State as an institution that responsible for organizing and carrying out the functions of the supervision. Implementation of the system of Government in the hisbah and the community can improve its efficiency in the system of Government and be able to describe the transparency of Government's response to the abuse of power that occurs, in addition to successfully eliminate any abuses and fraud in society. ${ }^{15}$

Supervision is very important in any activity especially in the financial system because it can guarantee well-implemented activity, with financial supervises, then it can be known to the level of success and failure of the financial system. It is referable to take steps forward in order to maintain the stability. ${ }^{16}$ Government's responsibility to protect society from acts of abuse of authority from institutions who manage the zakat required surveillance system so that it is ensured that the management of mustahik (zakat recipients) and the success of his crisp management of the charity with the increasing prosperity of society and in turn will change the status of the mustahik be muzaki (obligator zakat).

\section{Closing \\ Conclusion}

Based on the study, there are several points conclusion. First, historical value of zakat management during Islam's heyday can be matter of evaluation of zakat management system in Indonesia, those are: law enforcement action

\footnotetext{
14 Iwan Hermawan, "Analisis Eksistensi Sector Pertanian terhadap Pengurangan Kemiskinan di Pedesaan dan Perkotaan." Journal of Social and Development Rostrum. Vol.28 No.2 December 2012, Bandung: University Publising Centre (P2U-LPPM) Bandung Islamic University, page 141.

${ }^{15}$ Neneng Nurhasanah, "Pengawasan Islam dalam Operasional Lembaga Keuangan Syariah", Journal of Social and Development Rostrum. Vol. 29 No. 1 June 2013, Bandung: University Publising Centre (P2U-LPPM) Bandung Islamic University, page 14

${ }^{16}$ Hassanain Haykal and Ocktavianus Hartono, "Lembaga Pengawas Tunggal dalam Upaya Menciptakan Stabilitas Sistem Keuangan”. Jurnal Litigasi, Vol 12 No. 1 April 2011. Bandung: Law Faculty Pasundan University, page 931.
} 
towards society who do not want to pay zakat which is carried out by the Government and zakat manager; the pattern of ijtihad in deciding matters that affected the obligatory zakat, distribution system and more productive utilization of zakat; the existence of public confidence towards zakat manager; supervision towards rich group, estimating and then taking zakat from amuzaki (obligatory zakat) and monitor the collection of tithes became the main task of the zakat managers; and align the position of officers of taxes and the Manager of Zakat.

Second, Zakat management system so thus empowered to improve the welfare in fightagainst poverty efforts and mustahik (zakat's resceipent) be muzaki (zakat's obligatory) can be ran by: political will of government to explore national zakat potency with all kind of zakat obligatory fund and made zakat as part of state financial; zakat management system by the state in form of calculating, taking, and distributing to society; and monitoring System by government as kind of state's responsibility towards society's right to prevent authorization abuse.

\section{Recommendation}

Based on the discussion above, the recommendations can be given as follows: first, law enforcement during zakat law implementation by government and zakat manager is required; second, optimalization of zakat institution performance to improve society's trust; third, need monitoring from government towards zakat management to prevent authority abuse; and fourth, need study about national potency of zakat to be a part of state finance.

\section{References}

Asnaini. 2008. Zakat Produktif dalam Perspektif Hukum Islam. Pustaka Pelajar. Yogjakarta;

Chapra, M. Umar. 2001. Masa Depan Ilmu Ekonomi. Gema Insani Press. Bandung;

Circle Of Imformation and Development (CID). "Ringkasan Naskah Akademik Revisi UU Zakat". Zakat \& Empowering Journal, Vol. 176 August 2008. Jakarta: Circle of Information and Development (CID) Dhuafa's Wallet Cooperate with Islamic Studies and
Law Islamic of Law Faculty Universitas Indonesia;

Fuad, Fokky. "Islam dalam Dinamika Filsafat Hukum, antara Pemaknaan Nilai Konstruktif dan Destruktif." Lex Jurnalica Journal, Vol. 10 No. 2 August 2013 Edition. Jakarta: Esa Unggul University;

Haykal, Hassanain dan Ocktavianus Hartono. "Lembaga Pengawas Tunggal dalam Upaya Menciptakan Stabilitas Sistem Keuangan". Jurnal Litigasi, Vol. 12 No. 1 April 2011. Bandung: Law Faculty Pasundan University;

Hermawan, Iwan."Analisis Eksistensi Sector Pertanian terhadap Pengurangan Kemiskinan di Pedesaan dan Perkotaan". Rostrum Journal of Social and Development, Vol. 28 No. 2. December 2012. Bandung: Pusat Penerbitan Universitas (P2U-LPPM) University Publishing Centre (P2U-LPPM) Bandung Islamic University;

Mintarti, Nana et.al. "Kajian Perumusan Performance Indikator bagi Program Pemberdayaan Masyarakat Berbasis Zakat." Journal of Thought and Ideas. Zakat \& Empowering, Vol. 2. June 2009. Jakarta: IMZ The Indonesia Magnificence of Zakat;

Mulkanasir. "Mewujudkan Manajemen Zakat yang Modern dan Profesional". Empathy Journal of Social Welfare Studies, Vol. 1 No. 2 January 2013. Jakarta: Social Welfare Studies Program (Kessos) Syarif Hidayatullah Islamic State University;

Mulyana, Rahman. "Civil Governance Melalui Partisipasi Masyarakat dalam Proses Penyelenggaraan Pemerintah". Rostrum Journal of Social and Development, Vol.28 No.2 December 2012 Edition. Bandung: University Publishing Centre (P2U-LPPM) Bandung Islamic University;

Nasution, Mustafa Edwin. 2007. Pengenalan Ekslusif Ekonomi Islam. Jakarta: Kencana Prenada Media Group;

Nurhasanah, Neneng. "Pengawasan Islam Dalam Operasional Lembaga Keuangan Syariah." Rostrum Journal of Social and Development, Vol. 29, No. 1 June 2013 Edition. Bandung: Pusat Penerbitan Universitas (P2U-LPPM) University Publishing Centre (P2U-LPPM) Bandung Islamic University;

Perwitasari, Dyah Esthi. "Karakteristik Mustahik dalam Penggunaan Dana ZIS dan Pengaruhnya terhadap Probabitas Pengingkata Pendapatan Usaha (Studi Kasus Mustahik Pe- 
serta Program Pemberdayaan Ekonomi LAZ PKPU- Jakarta)". Eksist Journal of Islamic Business and Economics Financial, Vol. 4 No. 2 April-June 2008. Jakarta: Specifity of Islamic Economy and Financial of Middle East and Islamics Study Program of Postgraduate Program Universitas Indonesia;

Purwanto. "Ketahanan Pangan, Kemiskinan dan Pembangunan Wilayah Perdesaan." Journal of Social and Development, Vol. XX (1) June 2012. Bandung: University Publishing
Centre (P2U-LPPM) Bandung Islamic University;

Rochaeti, Etty. "Analisis Mengenai Zakat Profesi Kaitannya dengan Pajak Penghasilan". Legal Insight Journal, Vol. 24 No. 1 Februari 2011 Edition. Bandung: Law Faculty STHB;

Solihah, Cucu. "Negara Sejahtera dengan Memberdayakan Zakat melalui Fungsionalisasi Sistem Islam dan Hukum Administrasi Negara". Justicia Rostrum Legal Jounal. Vol. VI January-June 2014. Cianjur: Law Faculty Suryakancana University. 